\title{
Mobilisation of stored calcium in the neck region of human sperm - a mechanism for regulation of flagellar activity
}

\author{
KWEKU BEDU-ADDO ${ }^{1}$, SARAH COSTELLO ${ }^{2}$, CLAIRE HARPER ${ }^{3}$, GISELA MACHADO-OLIVEIRA ${ }^{2}$, \\ LINDA LEFIEVRE ${ }^{4}$, CHRISTOPHER FORD ${ }^{4}$, CHRISTOPHER BARRATT ${ }^{5}$ and STEPHEN PUBLICOVER ${ }^{2, *}$ \\ ${ }^{1}$ Kwame Nkrumah University of Science and Technology, Kumasi, Ghana, Africa, ${ }^{2}$ School of Biosciences, University of Birmingham, UK \\ ${ }^{3}$ School of Biological Sciences, University of Liverpool, UK ${ }^{4}$ Department of Medicine, University of Birmingham, UK and ${ }^{5}$ Medical \\ School, Ninewells Hospital, Dundee, UK
}

\begin{abstract}
Calcium signalling plays a pivotal role in sperm physiology, being intimately involved in the regulation of acrosome reaction, chemotaxis and hyperactivation. Here we describe briefly the mechanisms of calcium regulation in somatic cells and the ways in which these mechanisms have been adapted to function in mature spermatozoa. We then consider recent data from this and other laboratories on the responses of sperm to three compounds: progesterone and nitric oxide (both products of the cumulus oophorus) and 4-aminopyridine. All of these compounds induce calcium signals in the posterior sperm head and neck region and, when applied at appropriate concentrations, modify flagellar activity, causing asymmetric bending of the proximal flagellum. We argue that these effects reflect a common mode of action, mobilisation of calcium stored in the sperm neck region. Finally we consider the nature of calcium signalling pathways in sperm. We suggest that this highly specialised and extremely polarised cell, though working with the same calcium signalling 'tools' as those of somatic cells, employs them to generate unusually 'hard-wired' calcium signals that do not act to integrate stimuli. 'Leakage' between these calcium signalling pathways will generate inappropriate responses, compromising functioning of the cell.
\end{abstract}

KEY WORDS: sperm, calcium, nitric oxide, calcium store, hyperactivation

\section{Introduction}

Fluctuations in intracellular $\mathrm{Ca}^{2+}$ concentration $\left(\left[\mathrm{Ca}^{2+}\right]_{\mathrm{i}}\right)$ mediate rapid transmission of information from extracellular signals to internal response systems in all cells (Berridge, 1997). $\left[\mathrm{Ca}^{2+}\right]_{\mathrm{i}}$ is, in many ways, ideally suited for encoding of information in cells. Cytosolic concentration is maintained at extremely low levels compared to that in the surrounding extracellular medium, so $\mathrm{Ca}^{2+}$ flux into the cytoplasm, from an effectively limitless reservoir, can occur 'instantly' upon gating of $\mathrm{Ca}^{2+}$-permeable channels. Moreover, movement of 'small' numbers of ions can cause a large change in $\mathrm{P}_{\mathrm{Ca}}$ (Kretsinger, 1979). The use of $\left[\mathrm{Ca}^{2+}\right]_{\mathrm{i}}$ to encode information in the cytoplasm is, however, dependent upon the ability of the cell to generate signals of sufficient precision and complexity. In cells where $\left[\mathrm{Ca}^{2+}\right]_{\mathrm{i}}$ is used simultaneously to regulate multiple processes or where failure to localise a $\mathrm{Ca}^{2+}$ signal to its site of action may induce inappropriate or even toxic effects (Johnson and Chang, 2000; Berridge, 2006; Petersen et al., 2006), resolution of signals into specific domains of elevated $\left[\mathrm{Ca}^{2+}\right]$ (microdomains) will be particularly important. Conversely, in many cells $\left[\mathrm{Ca}^{2+}\right]_{\mathrm{i}}$ itself, and/or components of the $\mathrm{Ca}^{2+}$ signalling apparatus (such as membrane $\mathrm{Ca}^{2+}$ channels; Evans and Zamponi, 2006), are sites at which signal pathways converge. In this situation $\left[\mathrm{Ca}^{2+}\right]_{i}$ signalling acts as an integrative mechanism for diverse inputs (Fig. 1A).

Though understanding of the physiology of male germ cells is (arguably) some way behind that for somatic cells, it is well established that changes in $\mathrm{Ca}^{2+}$-signalling regulate or contribute to the regulation of many aspects of mammalian sperm function (Darszon et al., 2005; Felix, 2005; Jimenez-Gonzalez et al., 2006; Zhang et al., 2006; Publicover et al., 2007). $\left[\mathrm{Ca}^{2+}\right]_{i}$ has been shown to increase during capacitation in several mammalian species (Yanagimachi, 1994) including human (Baldi et al., 1991;

\footnotetext{
Abbreviations used in this paper: $\mathrm{Ca}^{2+}$ - calcium ion; EGTA, ethylene glycol tetraacetic acid; $\mathrm{IP}_{3} \mathrm{R}$, inositol tris phosphate receptor; NO, nitric oxide; PMCA, plasma membrane $\mathrm{Ca}^{2+}$-ATPase; RNE, redundant nuclear envelope; RyR, ryanodine receptor; SERCA, sarcoplasmic-endoplasmic reticulum $\mathrm{Ca}^{2+}$-ATPase; sGC, soluble guanylate cyclase; SOC, store-operated channel; SPCA, secretory pathway $\mathrm{Ca}^{2+}$-ATPase.
}

\footnotetext{
*Address correspondence to: Dr S.J. Publicover. School of Biosciences, University of Birmingham, Edgbaston, Birmingham, B15 2TT, UK. Fax: +44-121-414-5925. e-mail: s.j.publicover@bham.ac.uk
} 
Garcia and Meizel, 1999) and has both negative and positive actions on capacitation and related signalling events (Visconti et al., 2002). $\mathrm{Ca}^{2+}$ plays a central role in both acrosome reaction and sperm chemotaxis, with spermatozoa failing to perform either of these crucial functions in the absence of extracellular $\mathrm{Ca}^{2+}$ (Yanagimachi, 1994; Eisenbach and Giojalas, 2006). Furthermore, $\mathrm{Ca}^{2+}$ apparently switches on hyperactivation (Ho et al., 2002), a swimming pattern characterized by asymmetric flagellar beating and the development of high-amplitude flagellar waves, that is essential for fertilization. Here we briefly review current knowledge of $\left[\mathrm{Ca}^{2+}\right]_{\mathrm{i}}$ regulation in somatic cells and in sperm, then go on to examine the actions on human sperm of three diverse compounds, all of which modulate flagellar activity, apparently by mobilisation of stored $\mathrm{Ca}^{2+}$. Finally we consider the nature of sperm $\mathrm{Ca}^{2+}$-signalling as compared to that in more complex cells.

\section{Cellular $\left[\mathrm{Ca}^{2+}\right]$ regulation}

$\left[\mathrm{Ca}^{2+}\right]_{\mathrm{i}}$ in resting cells is strongly buffered (typically $<10^{-7} \mathrm{M}$ ) whereas $\left[\mathrm{Ca}^{2+}\right]_{0}$ and $\left[\mathrm{Ca}^{2+}\right]$ in intracellular organelles is in the range $10^{-4}-10^{-3} \mathrm{M}$ (Berridge, 2004). Regulation of $\left[\mathrm{Ca}^{2+}\right]_{\mathrm{i}}$ is achieved by a combination of pumps and channels on both the plasma and intracellular membranes (Fig. 1B). At the plasma membrane $\mathrm{Ca}^{2+}$ ATPases and/or $\mathrm{Na}^{+}-\mathrm{Ca}^{2+}$ exchangers extrude $\mathrm{Ca}^{2+}$ from the cell. Most cells express both $\mathrm{Ca}^{2+}$ ATPases and $\mathrm{Na}^{+}-\mathrm{Ca}^{2+}$ exchangers, but the relative contribution of the two components of membrane $\mathrm{Ca}^{2+}$ extrusion varies widely (Guerini et al., 2005). These pumps can be regulated in various ways including a simple feedback of $\left[\mathrm{Ca}^{2+}\right]_{\mathrm{i}}$ itself, which stimulates activity of plasma membrane $\mathrm{Ca}^{2+}-$ ATPases through the ubiquitous $\mathrm{Ca}^{2+}$ binding protein calmodulin (Guerini et al., 2005). Within the cell, the vast majority of $\mathrm{Ca}^{2+}$ is either bound to cytosolic proteins or sequestered into membranous organelles. The endoplasmic reticulum is the primary $\mathrm{Ca}^{2+}$ storage organelle (the sarcoplasmic reticulum in muscle), $\mathrm{Ca}^{2+}$ being pumped into the lumen of the compartment by sarcoplasmic-endoplasmic reticulum $\mathrm{Ca}^{2+}$ ATPases. Other organelles also act as $\mathrm{Ca}^{2+}$ stores, including the nuclear envelope, lysosomes and the golgi apparatus. Recently it has become apparent that a second type of ATPase, the secretory pathway $\mathrm{Ca}^{2+}$-ATPase contributes significantly to $\mathrm{Ca}^{2+}$ accumulation into storage organelles, particularly those derived from the golgi (Wuytack et al., 2003).

A diversity of $\mathrm{Ca}^{2+}$ channels are used to generate $\left[\mathrm{Ca}^{2+}\right]_{\mathrm{i}}$ signals (Fig. 1). At the plasma membrane there are voltageoperated $\mathrm{Ca}^{2+}$ channels (VOCCs; $\mathrm{Ca}^{2+}$-permeable channels sensitive to membrane potential), those activated by cyclic nucleotides (CNG channels), channels activated by ligand binding (both direct binding of the ligand to the channel and indirect activation via G-proteins) and channels which open upon mobilization of $\mathrm{Ca}^{2+}$ from intracellular stores (capacitative or storeoperated $\mathrm{Ca}^{2+}$ entry). At intracellular membranes there are at least two types of channels for mobilizing stored $\mathrm{Ca}^{2+}$. Inositol trisphosphate receptors $\left(\mathrm{IP}_{3} \mathrm{Rs}\right)$ are activated by generation of inositol trisphosphate $\left(\mathrm{IP}_{3}\right)$ which occurs at the plasma membrane. Ligand-activation of phospholipase $C$ results in breakdown of inositol 4,5 bisphosphate to $\mathrm{IP}_{3}$ and diacylglycerol. IP 3 is a small hydrophilic molecule that can diffuse through the cytoplasm to intracellular membranes, where it binds directly to the $\operatorname{IP}_{3} R$, causing it to open and releasing stored $\mathrm{Ca}^{2+}$ (Fig. 1B). Ryanodine receptors (RyRs; so-called because of their sensitivity to the plant alkaloid ryanodine) are sensitive to elevation of $\mathrm{Ca}^{2+}$ concentration (both cytoplasmic and in the lumen of the membranous organelle). These receptors appear primarily to 'amplify' or propagate $\left[\mathrm{Ca}^{2+}\right]_{i}$ signals generated by $\mathrm{Ca}^{2+}$ influx or store mobilization, a process called $\mathrm{Ca}^{2+}$-induced release of $\mathrm{Ca}^{2+}$ (Fig. 1B). RyRs in mammalian cells are also regulated by two other soluble molecules, cyclic ADP ribose (cADPR) and nicotinic acid-adenine dinucleotide phosphate (NAADP), both of which are generated in response to ligand binding at the plasma membrane and cause elevation of $\left[\mathrm{Ca}^{2+}\right]_{\mathrm{i}}$ (Fliegert et al., 2007).

In male germ cells the structural complexity that is characteristic of somatic cells (particularly the network of intra-membranous organelles) is greatly reduced during spermiogenesis. However, studies of $\mathrm{Ca}^{2+}$-regulation in sperm suggest that the 'standard' components and $\mathrm{Ca}^{2+-}$ signaling capabilities are retained, though possibly in modified form (Wennemuth et al., 2003; Publicover et al., 2007). Immunohistochemistry and Western blotting experiments show that several types of VOCCs are present (Felix, 2005; Jagannathan et al., 2006) and there is also good evidence for expression of ligand-activated channels (Meizel, 2004) and cyclic nucleotide-regulated channels (Weyand et al., 1994; Gauss et al., 1998; Galindo et al., 2000; Kobori et al., 2000) in mammalian and invertebrate sperm, In addition, a number of studies have shown that capacitative $\mathrm{Ca}^{2+}$ influx occurs in sperm (Blackmore, 1993; 1999; Dragileva et al., 1999; O'Toole et al., 2000; Rossato et al., 2001), indicating that store-operated channels are also present. $\mathrm{Ca}^{2+}$-ATPase extrusion pumps in the plasma membrane are probably the greatest contributors to $\mathrm{Ca}^{2+}$ buffering in mammalian sperm (Wennemuth et al., 2003) and are potentially involved in regulating $\left[\mathrm{Ca}^{2+}\right]$ changes during capacitation (Fraser and McDermott, 1992; DasGupta et al., 1994). Plasma membrane $\mathrm{Ca}^{2+}$ ATPase4 is expressed at high levels in the flagellum (Fig. 1B) and is very important in sperm motility (Okunade et al., 2004; Schuh et al., 2004). A plasma membrane $\mathrm{Ca}^{2+}$ ATPase is also expressed in sea urchin sperm, localized to the sperm head. Pharmacological inhibition of this pump disrupts control of $\left[\mathrm{Ca}^{2+}\right]_{\mathrm{i}}$ in the sperm and causes loss of flagellar activity (Gunaratne et al., 2006). $\mathrm{Na}^{+}-\mathrm{Ca}^{2+}$ exchangers are also present in sperm and contribute significantly to $\left[\mathrm{Ca}^{2+}\right]_{i}$ regulation (Wennemuth et al., 2003). It has been hypothesized that the $\mathrm{Na}^{+}-$ $\mathrm{Ca}^{2+}$ exchanger in sperm is regulated by caltrin, a low molecular weight protein originating from seminal plasma that binds to spermatozoa and is released during capacitation (Rufo et al., 1984). $\mathrm{A} \mathrm{Ca}^{2+} / \mathrm{H}^{+}$exchanger system has also been implicated in the regulation of intracellular $\mathrm{Ca}^{2+}$ (Fraser, 1995).

Intracellular $\mathrm{Ca}^{2+}$ storage and stimulus-activated $\mathrm{Ca}^{2+}$ mobilization in somatic cells is dependent primarily upon the endoplasmic reticulum. It might therefore be expected that this aspect of $\mathrm{Ca}^{2+}$-signalling would be largely lost in mature sperm. However, studies from many laboratories have demonstrated mobilization of stored $\mathrm{Ca}^{2+}$ in sperm, the most convincing evidence being that stimulus-induced $\mathrm{Ca}^{2+}$ signals can be observed in sperm incubated in $\mathrm{Ca}^{2+}$-free or very low $\mathrm{Ca}^{2+}$ medium (Dragileva et al., 1999; O'Toole et al., Ho and Suarez, 2001; Rossato et al., 2001; Harper et al., 2004; Gunaratne and Vacquier, 2006; Bedu-Ado et al., 2007). Treatment of sperm with pharmacological blockers of sarcoplasmic endoplasmic reticulum $\mathrm{Ca}^{2+}$ ATPases (primarily thapsigargin; Thastrup et al., 1990) to mobilize stored $\mathrm{Ca}^{2+}$ has 
also provided data consistent with the existence of $\mathrm{Ca}^{2+}$ stores (Blackmore, 1993; Meizel and Turner, 1993; Dragileva et al., 1999; O'Toole et al., 2000; Rossato et al., 2001; Dorval et al., 2003; Williams and Ford, 2003). However, interpretation of these data is complicated by the fact that most studies have used very high doses of thapsigargin (discussed in Harper et al., 2005) and the existence of sarcoplasmic endoplasmic reticulum $\mathrm{Ca}^{2+} \mathrm{AT}$ -
Pases in sperm is controversial (Harper et al., 2005; Gunaratne and Vacquier 2006b; Lawson et al., 2007; see above). Though a specific (diagnostic) pharmacological tool is not available, it appears that both human and sea urchin sperm express the nonsarcoplasmic endoplasmic reticulum $\mathrm{Ca}^{2+} \mathrm{ATPase} \mathrm{Ca}^{2+}$ store pump secretory pathway $\mathrm{Ca}^{2+}$ ATPase and that this pump plays a significant role in sperm $\mathrm{Ca}^{2+}$ storage (Harper et al., 2005;

A

Fig. 1. $\mathrm{Ca}^{2+}$ signalling. (A) $\mathrm{Ca}^{2+}$ signalling 'strategies'. (i) Situation in which $\left[\mathrm{Ca}^{2+}\right]_{i}$ integrates multiple inputs, all of which are regulating the same cellular activity. Stimulusinduced $\mathrm{Ca}^{2+}$-signalling in mast cells and neutrophils shows some resemblance to this model. In these cells a range of ligands may cause cell degranulation (exocytosis of a population of exocytotic granules). These ligands act by inducing receptor clustering, which mobilises stored $\mathrm{Ca}^{2+}$ and permits $\mathrm{Ca}^{2+}$ entry, causing a 'global' $\left[\mathrm{Ca}^{2+}\right]_{i}$ signal (Furuno, 2005). (ii) $\mathrm{A}$ cell in which $\mathrm{Ca}^{2+}$ domains (shown in green and yellow) are generated and contained by the $\mathrm{Ca}^{2+}$-signalling toolkit. Within these domains integration of more than one input can occur, but domains are separated, allowing discrete control of $\mathrm{Ca}^{2+}$ regulated processes. (iii) A 'hard wired' system in which each type of stimulus generates a separate $\mathrm{Ca}^{2+}$ signal in a separate domain, with little if any scope for integration of inputs by the $\mathrm{Ca}^{2+}$-signalling system. $\mathrm{Ca}^{2+}$ signalling in sperm appears to use this system, or something close to it (see text). (B) Simplified summary of $\left[\mathrm{Ca}^{2+}\right]_{i}$ signalling 'toolkits' in a somatic cells (left) and a sperm (right). Somatic cell diagram does not include all known or putative components. Sperm signalling components shown are 'best guess' on the basis of available evidence. In the somatic cell $\left[\mathrm{Ca}^{2+}\right]_{i}$ is controlled by a range of channels (shown by rectangles) and pumps (shown by circles) in the plasma and intracellular membranes. Pumps and channels for uptake and mobilisation of stored $\mathrm{Ca}^{2+}$ are shown on the stack of intracellular membranes on the left. These are situated primarily on the endoplasmic reticulum but are also present on nuclear and Golgi membranes. Agonist binding and trans-membrane voltage regulate $\mathrm{Ca}^{2+}$-permeable channels in the plasma membrane. Agonist-induced generation of $\mathrm{IP}_{3}$ and cAMP regulate $\mathrm{Ca}^{2+}$-perme-

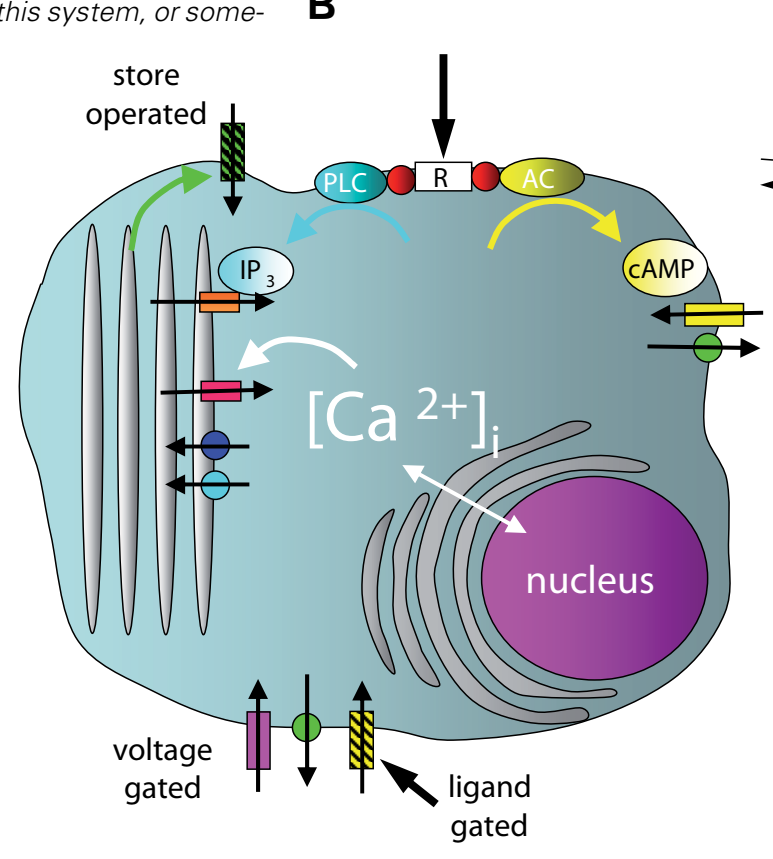

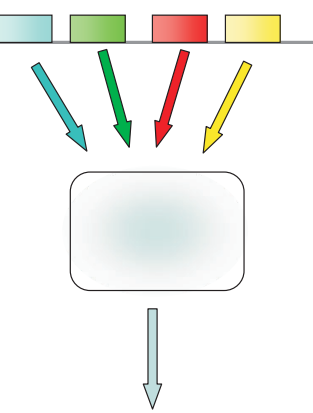

integrated response (ii)

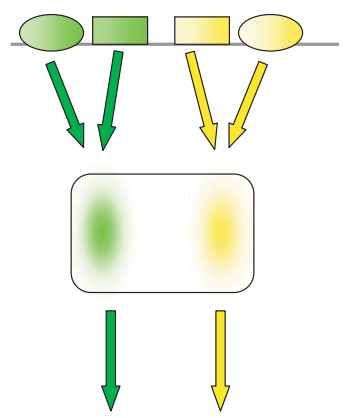

integrated discrete responses (iii)

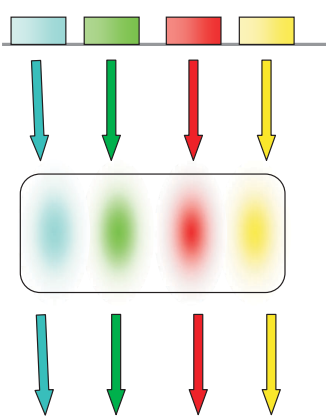

'hard-wired' discrete, responses

able channels in intracellular (blue arrow) and plasma (yellow arrow) membranes respectively. Mobilisation of stored Ca ${ }^{2+}$ activates store-operated channels in the plasma membrane (green arrow). Ca ${ }^{2+}$-ATPase pumps and $\mathrm{Na}^{+} / \mathrm{Ca}^{2+}$ exchangers extrude $\mathrm{Ca}^{2+}$ at the plasma membrane (green circles), SERCAs and SPCAs pump Ca ${ }^{2+}$ into intracellular organelles (blue circles). In the sperm the same components are present but many show a clearly restricted distribution. Complexity of intracellular membranes is greatly reduced and the endoplasmic reticulum is lost. Intracellular pumps and channels are present on the acrosome and in the sperm neck region on the redundant nuclear envelope and calreticulin containing vesicles. CatSpers (specific to sperm; red rectangle) are restricted to the principal piece of the sperm. PMCA4 is the primary plasma membrane Ca ${ }^{2+}$ ATPase in mammalian sperm and is restricted to the principal piece of the flagellum (Okunade et al., 2004; Schuh et al., 2004). AC, adenyl cyclase; CNG channel, cyclic nucleotide regulated channel; PLC, phospholipase $C$; PMCA, plasma membrane $C a^{2+}$-ATPase; $R$, ligand receptor; $R N E$, redundant nuclear envelope; SERCA, sarcoplasmic-endoplasmic reticulum Ca ${ }^{2+}$-ATPase; SOC, store-operated channel; SPCA, secretory pathway Ca ${ }^{2+}-A T P a s e$. 
Gunaratne and Vacquier 2006).

There is evidence for the presence of at least three discrete intracellular $\mathrm{Ca}^{2+}$ stores in mammalian sperm. The acrosome is able to store $\mathrm{Ca}^{2+}$ (Fig. 1B), and has $\mathrm{IP}_{3} \mathrm{Rs}$ on its outer membrane (Walensky and Snyder, 1995; Kuroda et al., 1999; Rossato et al., 2001; De Blas et al., 2002; Fig. 1B). Mobilisation of $\mathrm{Ca}^{2+}$ from this store is necessary for acrosome reaction, the acrosomal store controlling it's own exocytosis (Herrick et al., 2005). A second $\mathrm{Ca}^{2+}$ store (or stores) is present in the sperm neck region (Fig. $1 \mathrm{~B})$. The identity of the membranous compartment in which $\mathrm{Ca}^{2+}$ is stored is not yet clear, but it appears to involve the redundant nuclear envelope (RNE) and/or calreticulin-containing vesicles in the cytoplasmic droplet (Ho and Suarez, 2002; Naaby Hansen et al., 2001; Ho and Suarez, 2003; Harper et al., 2004, 2005). Both $I_{3} R$ and RyRs have been localized to this region (Fig. 1B) and the store may therefore respond both directly to $\mathrm{IP}_{3}$ and also by $\mathrm{Ca}^{2+}$ induced $\mathrm{Ca}^{2+}$ release. In addition, as in somatic cells, sperm mitochondria can accumulate $\mathrm{Ca}^{2+}$. Wennemuth et al., (2003) estimated that the contribution of the mitochondrial $\mathrm{Ca}^{2+}$ uniporter to the rate of $\mathrm{Ca}^{2+}$ clearance was similar to that of $\mathrm{Na}^{+}-\mathrm{Ca}^{2+}$ exchangers, whereas the plasma membrane $\mathrm{Ca}^{2+}$ ATPase removed $\mathrm{Ca}^{2+}$ approximately 3 times more rapidly.

\section{$\mathrm{Ca}^{2+}$ signals in sperm}

The very small size and rapid motility of sperm are such that application of standard cell physiological techniques is technically demanding. Furthermore, studies on the physiological activity and agonist-induced responses of cell populations can mask important events that occur in only a proportion of 'normal' and responsive cells, a particular problem with human sperm (Lefievre et al., 2003). However, technical and experimental innovations have contributed greatly to overcoming these problems such that the last 10 years have seen great progress in our understanding of sperm physiology in general and $\mathrm{Ca}^{2+}$ signaling in particular (Publicover et al., 2007). It is now apparent that vertebrate and invertebrate sperm can generate a number of highly sophisticated, spatiotemporal $\mathrm{Ca}^{2+}$ signals that selectively can regulate specific activities (acrosome reaction, chemotaxis, hyperactivation). Here we concentrate primarily on the $\left[\mathrm{Ca}^{2+}\right]_{i}$ signals that occur in human sperm exposed to three diverse compounds; progesterone, nitric oxide and 4-aminopyridine (a highly effective inducer of hyperactivation in human sperm; Gu et al., 2004) and we consider the ability of the sperm, a cell with an extremely small cytoplasmic volume, to use $\mathrm{Ca}^{2+}$ to regulate a number of discrete activities.

\section{Progesterone, $\mathrm{Ca}^{2+}$ signalling and regulation of sperm func- tion}

Progesterone is present in high (micromolar) concentrations in the follicular fluid (Osman et al., 1989; Thomas and Meizel, 1989) and is synthesized, both before and after ovulation, by the cells of the cumulus oophorus that surround the egg. For human spermatozoa, progesterone is the only biological agonist for which detailed study has been undertaken (Kirkman-Brown etal., 2002). Exposure to progesterone, at nanomolar to micromolar doses, causes an immediate (within seconds) increase in $\left[\mathrm{Ca}^{2+}\right]_{i}$ in both capacitated and non-capacitated human sperm (Thomas and

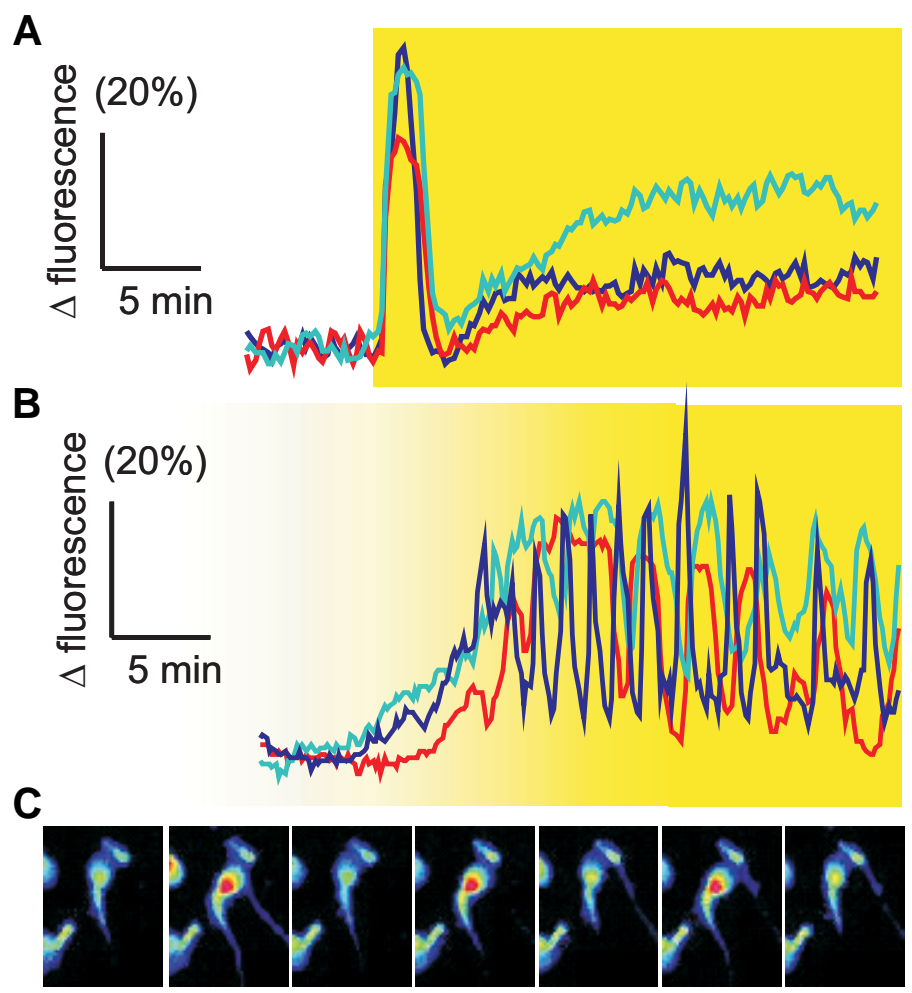

Fig. 2. $\mathrm{Ca}^{2+}$ signals evoked by progesterone in immobilised human sperm. (A) Biphasic elevation of $\left[\mathrm{Ca}^{2+}\right]_{i}$ (change in fluorescence of Oregon Green BAPTA 1) in response to application of $3.1 \mu \mathrm{M}$ progesterone (shown by yellow shading) as a concentration 'step'. Responses of three separate cells are shown. (B) Response to a progesterone applied as a logarithmic concentration gradient (0-3.1 $\mu \mathrm{M}$; shown by yellow shading). Cells show a slow rise in $\left[\mathrm{Ca}^{2+}\right]_{i}$ (change in fluorescence of Oregon Green BAPTA 1) upon which, in up to $50 \%$ of cells, oscillations are superimposed. Responses of three separate cells are shown each of which generated $\left[\mathrm{Ca}^{2+}\right]_{i}$ oscillations. (C) Series of pseudo-coloured images (warm colours show high $\left[\mathrm{Ca}^{2+}\right]_{i}$ ) of a sperm that is generating $\mathrm{Ca}^{2+}$ oscillations. The seven images show peaks and troughs for three complete cycles. During each of the $\left[\mathrm{Ca}^{2+}\right]_{i}$ peaks there is a marked flexure (a clear change in angle between the midline of the head and proximal flagellum), which is always in the same direction and 'relaxes' during $\left[\mathrm{Ca}^{2+}\right]_{i}$ troughs. Images are at approximately $50 \mathrm{~s}$ intervals.

Meizel, 1989; Blackmore et al., 1990, 1991; Baldi et al., 1991; Bedu-Addo et al., 2005). In capacitated cells exposure to progesterone causes a dose-dependent induction of acrosome reaction, apparently dependent upon this $\mathrm{Ca}^{2+}$ influx (Yanagimachi, 1994b; Blackmore etal., 1990; Baldi et al., 1991; Harper etal., 2003). The kinetics of acrosome reaction within a population of cells closely follow the kinetics of $\left[\mathrm{Ca}^{2+}\right]_{i}$ elevation (Harper et al., 2006). The very short latency of the response to progesterone, and the ability of progesterone to exert a similar effect even when presented as a membrane-impermeant conjugate, indicate a mode of action involving a cell surface receptor for progesterone and not the classical intracellular receptor that regulates gene transcription (Blackmore et al., 1991; Meizel and Turner, 1991). The nature of this receptor for progesterone is still unresolved, but it is noteworthy that exposure to the steroid induces a prolonged, relative or complete refractory period to further stimulation (Aitken et al., 1996; Harper et al., 2003). This suggests that the receptor 
activation-signal transduction pathway is subject to a rapid down regulation process that has a profound and prolonged effect on the fertilizing physiology of the sperm (Aitken et al., 1996).

Stimulation of human sperm with micromolar doses of progesterone increases $\left[\mathrm{Ca}^{2+}\right]_{\mathrm{i}}$ in a biphasic manner (Meizel et al., 1997: Kirkman-Brown et al., 2000: Bedu-Addo et al., 2005: Bedu-Addo et al., 2007; Fig. 2A). An initial, rapid elevation of $\left[\mathrm{Ca}^{2+}\right]_{\mathrm{i}}$ is observed which initiates in the mid-head region, peaks within 15 $\mathrm{s}\left(\right.$ at $\left.37^{\circ} \mathrm{C}\right)$ and then decays over the following 40-60 s (Blackmore et al., 1990: Foresta et al., 1993: Plant et al., 1995: Aitken et al., 1996: Tesarik et al., 1996: Meizel etal., 1997: Harper et al., 2003). The amplitude (but not the kinetics) of the transient $\left[\mathrm{Ca}^{2+}\right]_{\text {i }}$ response shows strong dose sensitivity over the range of $0.3 \mathrm{nM}$ $3 \mu \mathrm{M}$, saturating at $\approx 300 \mathrm{nM}\left(\mathrm{ED}_{50} \approx 30-50 \mathrm{nM}\right)$ in both sperm populations (Baldi et al., 1991) and at the single cell level (Harper et al., 2003). The frequency of occurrence (\% cells responding to progesterone) is largely dose-independent (Harper et al., 2003). This $\left[\mathrm{Ca}^{2+}\right]_{\mathrm{i}}$ transient is apparently mediated by $\mathrm{Ca}^{2+}$ influx since it is greatly inhibited in the presence of $\mathrm{La}^{3+}$ (a non selective $\mathrm{Ca}^{2+}$ channel blocker), and is abolished when the extracellular medium is supplemented with the $\mathrm{Ca}^{2+}$ chelator EGTA (Blackmore et al., 1990: Plant et al., 1995: Aitken et al., 1996: Bedu-Addo et al., 2007). However, recent data suggest that the $\mathrm{Ca}^{2+}$ signaling cascade activated by progesterone may be more complex. Though the population response to progesterone is not detectable in EGTA-buffered medium, approximately $5 \%$ of cells bathed in this medium for 4-5 min do respond to progesterone with a small $\left[\mathrm{Ca}^{2+}\right]_{\mathrm{i}}$ transient (Bedu-Addo et al., 2007). More prolonged incubation abolishes this response, suggesting that stored $\mathrm{Ca}^{2+}$ is mobilized by progesterone but that incubation in EGTA-containing medium rapidly depletes the progesterone-mobilised store (Bedu-Addo et al., 2007). If EGTA is not used but $\mathrm{Ca}^{2+}$ is simply omitted from the saline (nominally $\mathrm{Ca}^{2+}$-free, conditions) $\left[\mathrm{Ca}^{2+}\right]_{0}$ is $<5 \mu \mathrm{M}$ (Harper et al., 2004). Under these conditions a response to progesterone is clearly detectable. The $\left[\mathrm{Ca}^{2+}\right]_{\mathrm{i}}$ transient is smaller, has a longer latency of activation (at least $4 \mathrm{~s}$ ) and peaks later. We have concluded that the transient response of human spermatozoa to progesterone is a combination of $\mathrm{Ca}^{2+}$-influx and mobilization of a labile, EGTA-sensitive store. (Bedu-Addo et al., 2007).

Perhaps more significantly, it appears that progesterone not only mobilises stored $\mathrm{Ca}^{2+}$, but elicits $\mathrm{Ca}^{2+}$ signals in sperm of a complexity comparable with those observed in somatic cells. When sperm are stimulated with a progesterone gradient (to represent more closely the stimulus that a sperm will encounter upon approaching the oocyte) there is no initial transient (as described above) but all cells show a slow, tonic rise in $\left[\mathrm{Ca}^{2+}\right]_{\text {i }}$ upon which (in up to $50 \%$ of cells) $\mathrm{Ca}^{2+}$ oscillations in the rear of the sperm head and the midpiece are superimposed (Harper et al., 2004; Fig. 2B). Oscillations can also be induced by application of $3 \mu \mathrm{M}$ progesterone as a concentration 'step', following the initial $\left[\mathrm{Ca}^{2+}\right]_{\mathrm{i}}$ transient, but the number of cells in which this signalling pattern occurs is low (10-20\%; Harper et al., 2004; KirkmanBrown et al., 2004; Aitken and McLaughlin, 2007). These $\left[\mathrm{Ca}^{2+}\right]_{i}$ oscillations persist when saline in the recording chamber (sEBSS) is replaced with saline with no added $\mathrm{Ca}^{2+}$ (nominally $\mathrm{Ca}^{2+}$-free, see above) and their amplitude and definition often increases, indicating that they are primarily dependent on store mobilisation. Intriguingly, when sEBSS is replaced by nominally $\mathrm{Ca}^{2+}$-free saline before $3 \mu \mathrm{M}$ progesterone is applied, the proportion of cells in which progesterone induces oscillations is markedly increased ( $\approx 50 \%$; Bedu-Addo et al., 2007; CV Harper, unpublished data). However, when cells were transiently (4 min) exposed to EGTAbuffered saline, then superfused with nominally $\mathrm{Ca}^{2+}$-free saline prior to stimulation, oscillations occurred in only $1 \%$ of cells (Bedu-Addo et al., 2007). Thus it appears that, when presented 'physiologically', progesterone causes a modest $\mathrm{Ca}^{2+}$ influx (with no initial transient component) and activates mobilisation of an EGTA-sensitive $\mathrm{Ca}^{2+}$ store that, under appropriate circumstances, will cyclically empty and refill, producing a series of $\left[\mathrm{Ca}^{2+}\right]_{i}$ oscillations. But what is this store and how is it mobilised?

Characterization of progesterone-induced $\left[\mathrm{Ca}^{2+}\right]_{i}$ oscillations in human sperm suggests that they are generated by a form of $\mathrm{Ca}^{2+}$-induced $\mathrm{Ca}^{2+}$ release. Oscillations were not affected by inhibition of $\mathrm{IP}_{3}$ generation or by 2-aminoethoxydiphenyl borate, a membrane-permeant inhibitor of $\mathrm{IP}_{3} \mathrm{Rs}$. In contrast, pharmacological modulators of RyRs, which mediate $\mathrm{Ca}^{2+}$-induced $\mathrm{Ca}^{2+}$ release, had marked effects on oscillations. Ryanodine rapidly altered the frequency of oscillations (in a dose-dependent manner) and both ryanodine and caffeine converted irregular $\mathrm{Ca}^{2+}$ 'ripples' into an organised series of transients (Harper et al., 2004). Ryanodine and 4-chloro-m-cresol (a potent agonist of RyR 1 and 2; Zorzato et al., 1993; Choisy et al., 1999; Matyash et al., 2002) both elevate $\left[\mathrm{Ca}^{2+}\right]_{\mathrm{i}}$ in human sperm, inducing oscillations in $\approx 12 \%$ and $\approx 9 \%$ of cells respectively (Machado-Oliveira, unpublished data). This is consistent with our conclusion that tonic, lowlevel $\mathrm{Ca}^{2+}$ influx is required to maintain cyclic filling and emptying of the store (Harper et al., 2004). Using both BODIPY ryanodine (live cells; Harper et al., 2004) and antibodies against RyR 1 and 2 (a gift from Professor FA Lai, University of Cardiff) we have observed staining primarily in the neck region of human sperm. Calreticulin-containing vesicles occur in this region of human sperm (Naaby-Hansen et al., 2001). These findings are in agreement with our observation that $\left[\mathrm{Ca}^{2+}\right]$ oscillations are primarily localised to this region (Harper et al., 2004) and suggest that it is the sperm neck $\mathrm{Ca}^{2+}$ store(s) (see above) that generates these complex $\mathrm{Ca}^{2+}$ signals. Studies by Suarez and colleagues have shown the presence of a $\mathrm{Ca}^{2+}$ store in this region in bovine sperm, which they identified as the redundant nuclear envelope (RNE; Ho and Suarez, 2001; 2003). Their work showed that this structure bore $\mathrm{IP}_{3} \mathrm{Rs}$ (as do the calreticulin-containing vesicles of human sperm) but they did not detect RyRs. Mobilization of this store appears to play a role in regulation of the flagellum in bovine and murine sperm (Ho and Suarez, 2001;2003; Marquez et al., 2007), being sufficient at least to initiate hyperactivation.

As noted above (in the section on cellular calcium regulation), the presence (and more particularly the function) of sarcoplasmic endoplasmic reticulum $\mathrm{Ca}^{2+}$ ATPase in sperm is disputed (Harper et al., 2005), though recent studies do appear to confirm that this ATPase is present (Lawson etal., 2007). However, progesteroneinduced $\left[\mathrm{Ca}^{2+}\right]_{\mathrm{i}}$ oscillations show very little sensitivity to the SERCA-inhibitor thapsigargin (Harper et al., 2004, 2005), indicating that SERCAs do not contribute significantly to filling of the progesterone-mobilised $\mathrm{Ca}^{2+}$ store. Recently another intracellular $\mathrm{Ca}^{2+}$ store pump, secretory pathway $\mathrm{Ca}^{2+}$ ATPase, has been detected in both human and sea urchin sperm. Immunohistochemistry suggests that this ATPase is localised to the posterior head and/or midpiece (Harper et al., 2005; Gunaratne and 
Fig. 3. $\mathrm{Ca}^{2+}$ signals evoked by nitric oxide in immobilised human sperm. (A) Model for probable progesterone (yellow) and nitric oxide (blue) stimulus profiles encountered by the sperm during approach the oocyte. Progesterone shows a clear and probably chemotactic concentration gradient within and around the oocyte-cumulus complex. Nitric oxide is present at significant concentration within the cumulus due to tonic activity of nitric oxide synthase in cumulus cells, but does not form a concentration gradient by diffusion due to its reactivity and consequent short halflife. (B) Left: slow rise in $\left[\mathrm{Ca}^{2+}\right]_{i}$ (change in fluorescence of Oregon Green BAPTA 1) upon exposure to $100 \mu \mathrm{M}$ spermine NONOate. Responses of four separate cells are shown. Right: Treatment with $100 \mathrm{pM}$ progesterone (yellow shading) causes a small increase in $\left[\mathrm{Ca}^{2+}\right]_{i}$ in some cells. In all of these 4 cells (including one [blue trace] which showed no detectable response to $100 \mathrm{pM}$ progesterone) subsequent application of spermine NONOate lblue shading) caused a large transient increase in $\left[\mathrm{Ca}^{2+}\right]_{i}$ followed by oscillations. In some cells the response to nitric oxide under these conditions was very different (see text). (C) Series of pseudo-coloured images (warm colours show high $\left[\mathrm{Ca}^{2+}\right]_{i}$ ) of a sperm stimulated with nitric oxide after pre-treatment with $100 \mathrm{pM}$ progesterone. Image series shows peaks and troughs of the initial $\left[\mathrm{Ca}^{2+}\right]_{i}$ transient and the first two $\mathrm{Ca}^{2+}$ oscillations. During each of the $\left[\mathrm{Ca}^{2+}\right]_{i}$ peaks there is a marked flexure (a clear change in angle between the midline of the head and proximal flagellum), which is always in the same direction and 'relaxes' during $\left[\mathrm{Ca}^{2+}\right]_{i}$ troughs. Images are at approximately $50 \mathrm{~s}$ intervals.
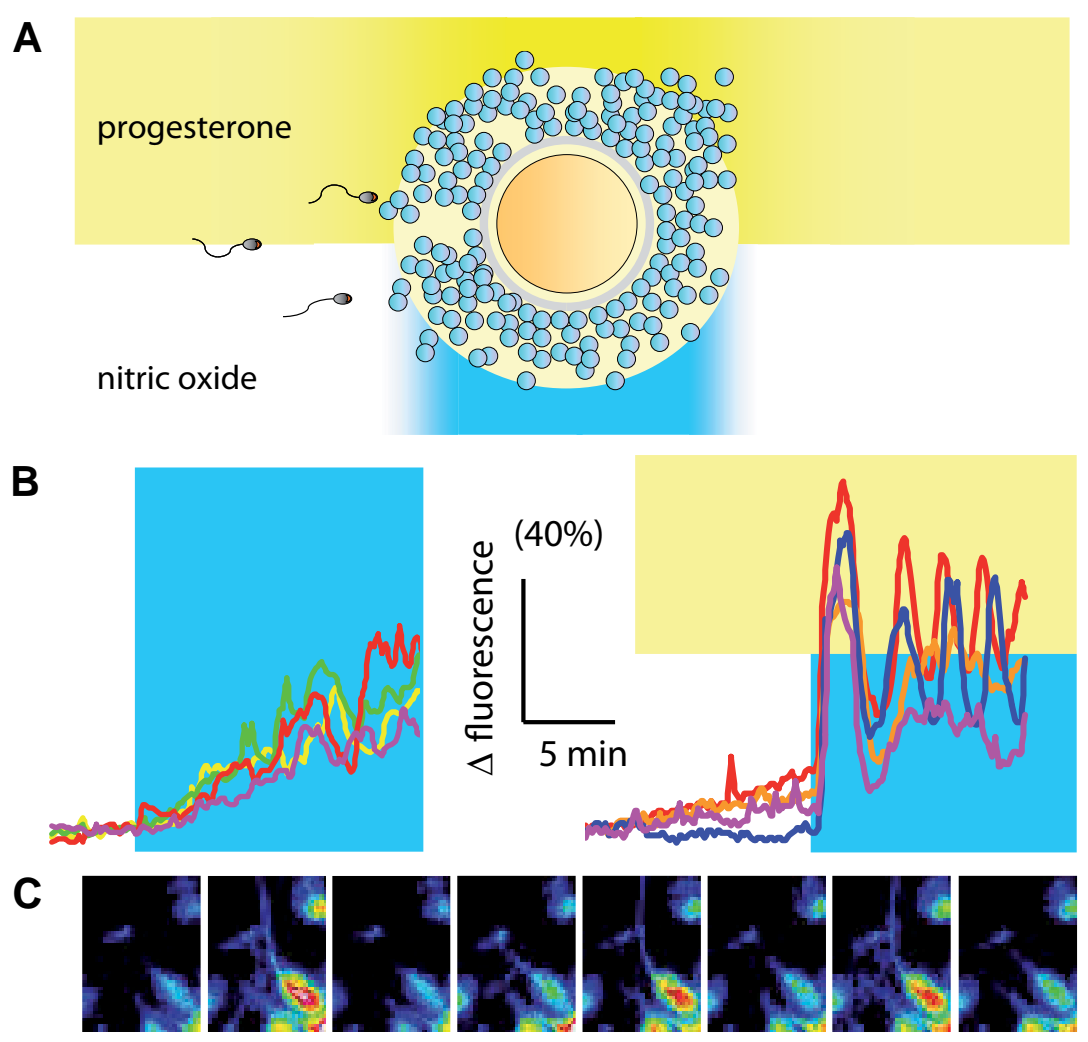

Vacquier, 2006) and it appears to participate in refilling of the store responsible for progesterone-induced $\mathrm{Ca}^{2+}$ oscillations (Harper et al., 2005).

The ability of progesterone to induce acrosome reaction in mammalian sperm is, in the context of sperm function, surprising. If progesterone induces acrosome reaction in vivo, in sperm approaching the cumulus-oocyte complex, or even in cells entering the cumulus, this will reduce, or even negate, their ability to fertilise (Lui et al., 2006). We have argued that induction of acrosome reaction by progesterone may reflect failure of the sperm's $\left[\mathrm{Ca}^{2+}\right]_{\mathrm{i}}$ homeostatic mechanisms, potentially allowing removal of poor quality cells from the 'race' to fertilise (Harper and Publicover, 2005). It appears that regulation of flagellar activity, modulating motility and/or chemotaxis, may be the primary function of progesterone-induced $\left[\mathrm{Ca}^{2+}\right]_{i}$ signalling. Micromolar doses of progesterone directly stimulate hyperactivated motility in human and other mammalian sperm (Uhler et al., 1992; Yang et al., 1994; Jaiswal et al., 1999; Gwathmey et al., 2000). We consider this to be a reflection of $\mathrm{Ca}^{2+}$-induced $\mathrm{Ca}^{2+}$ release, from the membranous store(s) in the neck region of the sperm that occurs upon progesterone stimulation. Increased flagellar excursion and flagellar asymmetry occur during the initial progesterone-induced $\left[\mathrm{Ca}^{2+}\right]_{\mathrm{i}}$-transient both in cells incubated under standard conditions and in cells bathed in medium with no added $\mathrm{Ca}^{2+}$ (Bedu-Addo et al., 2007). In contrast, when cells are briefly pre-treated with EGTA before returning them to medium with no added $\mathrm{Ca}^{2+}$, which apparently abolishes progesterone-induced store mobilisation (see above), the effect of progesterone-treatment on flagellar motility is lost (Bedu-Addo et al., 2007). Furthermore, during $\left[\mathrm{Ca}^{2+}\right]_{i}$ oscillations, which do not induce acrosome reac- tion, some cells show bursts of flagellar activity (Harper et al., 2004) and many show flagellar asymmetry (unilateral bending of the proximal flagellum; Fig. $2 \mathrm{C}$ ) synchronised to the peaks of the $\mathrm{Ca}^{2+}$ oscillations. Thus we propose that treatment with progesterone induces phasic mobilisation of the sperm neck store, causing intermittent modulation of flagellar activity. In bovine sperm, tonic mobilisation of $\mathrm{Ca}^{2+}$ from what is apparently the equivalent structure, causes hyperactivation (Ho and Suarez, 2001; 2003).

\section{Nitric oxide and sperm $\mathrm{Ca}^{2+}$ signalling and interaction with progesterone}

Studies in our laboratory indicate that the cells of the cumulus oophorus express nitric oxide synthase. Furthermore, cumulus cells in vitro synthesise NO; production greatly exceeding any that may in occurring sperm (WCL Ford and L Lefievre, unpublished data; Machado-Oliveira et al., in prep). Thus as sperm approach or enter the cumulus they probably experience increased concentrations of NO (Fig. 3A). Application of NO to mammalian sperm in vitro has functional effects. A number of laboratories have reported that treatment of human sperm with NO donors induces acrosome reaction (Zamir etal., 1995; Herrero et al., 1997; Revelli et al., 2001) and there is also good evidence that exposure to NO has effects on sperm motility. High concentrations of NO, particularly after prolonged incubation, can be toxic to sperm, reducing motility severely (Joo et al., 1999; Wu et al., 2004; 2004b), but exposure to low concentrations of NO donors over short periods is reported to stimulate motility (Herrero et al., 1994; Zhang and Zheng, 1996; Yeoman et al., 1998). Since stimulation of acrosome reaction and hyperactivation may both involve mobilisation of $\mathrm{Ca}^{2+}$, we have investigated whether incu- 
bation of human sperm with NO donors causes modulation of $\left[\mathrm{Ca}^{2+}\right]_{\mathrm{j}}$.

Slow release donors of NO (such as spermine NONOate) cause a sustained rise in $\left[\mathrm{Ca}^{2+}\right]_{i}$ in human sperm (Fig. 3B). This effect of $\mathrm{NO}$ is modest (far smaller than the response to progesterone) but persistent, and is not modulated by omission of $\mathrm{Ca}^{2+}$ from the saline (nominally $\mathrm{Ca}^{2+}$-free). In contrast, the response to treatment with 8-bromo-cGMP, which will activate cyclicnucleotide regulated membrane $\mathrm{Ca}^{2+}$ channels, is reduced by $>80 \%$ under these conditions. Thus the action of $\mathrm{NO}$ on $\left[\mathrm{Ca}^{2+}\right]_{i}$ of human sperm reflects primarily the mobilisation of a $\mathrm{Ca}^{2+}$ store. Furthermore, use of pharmacological agents and manipulation of $\mathrm{Ca}^{2+}$ fluxes (see above) strongly suggests that this action of $\mathrm{NO}$ is not due to activation of soluble guanylate cyclase (sGC) but is a direct effect of the S-nitrosylation of sperm proteins (Machado-Oliveira et al., in prep). RyR are modulated both positively and negatively by NO, primarily by Snitrosylation; Stoyanovsky et al., 1997; Zahradnikova et al., 1997; Xu et al., 1998; Hart and Dulhunty, 2000; Li et al., 2000; Heunks et al., 2001; Zima and Blatter, 2006) and we have shown that RyR 2 is a target for S-nitrosylation in human sperm (Lefievre et al., 2007). Since the action of progesterone to mobilise stored $\mathrm{Ca}^{2+}$ in human sperm involves RyR or RyR-like proteins, we have investigated possible interaction between these agonists. In initial experiments where progesterone (3.2 $\mu \mathrm{M})$ was applied to sperm pre-treated with spermine NONOate, the $\left[\mathrm{Ca}^{2+}\right]_{i}$ transient response (see Fig. $2 \mathrm{~A}$ ) was particularly large in many cells and was often prolonged. Even more intriguing is our observation that pre-treatment with progesterone at very low concentration (100 pm - $1 \mathrm{nM}$ ) before application of a nitric oxide donor (a sequence of events that is more likely to reflect the stimuli encountered in vivo; Fig. $3 \mathrm{~A}, \mathrm{~B}$ ) can cause dramatic modification of the response to NO (MachadoOliveira et al., unpublished data). 100 pM progesterone induces a small rise in $\left[\mathrm{Ca}^{2+}\right]_{i}$ in some cells, but in many there is no discernible effect. However, the response to subsequent application of the NO donor spermine NONOate is, in many cells,

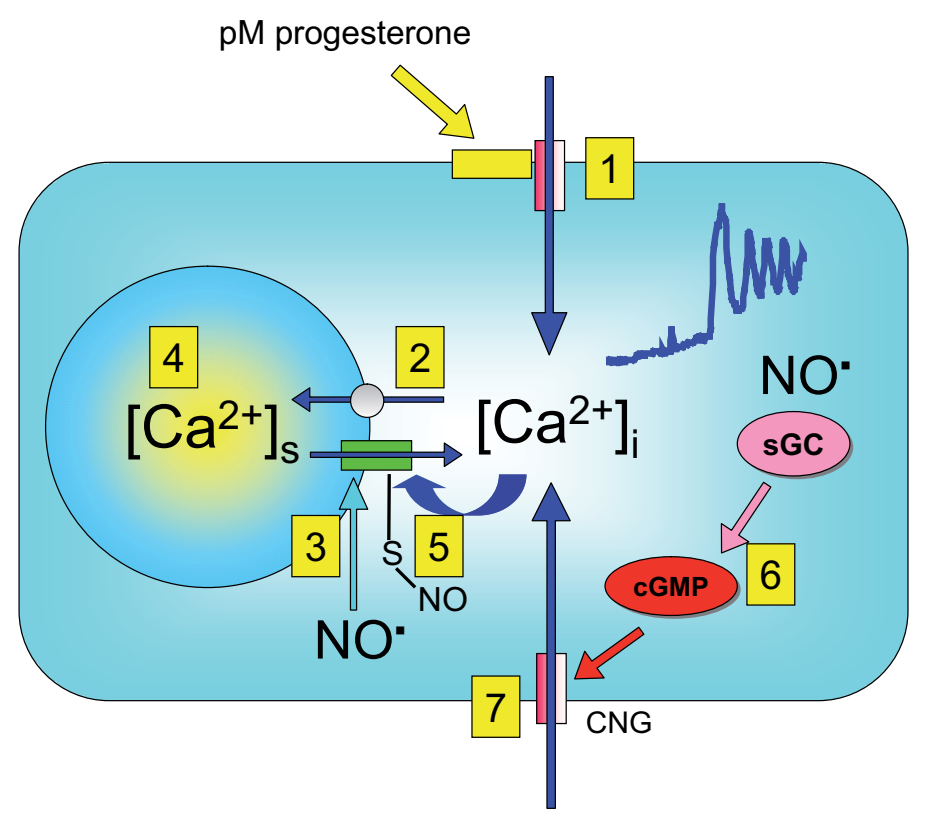

transformed. NO, instead of causing a tonic elevation of $\left[\mathrm{Ca}^{2+}\right]_{i}$, induces an immediate, large, $\mathrm{Ca}^{2+}$ transient which is often followed by $\mathrm{Ca}^{2+}$ oscillations (Fig. 3B). Since progesteroneinduced, phasic mobilisation of $\mathrm{Ca}^{2+}$ stored in the sperm neck region causes phasic modulation of flagellar beat (see above), we investigated flagellar activity in sperm that show a $\left[\mathrm{Ca}^{2+}\right]_{i}$ transient upon exposure to NO. In poorly immobilised cells bending of the proximal flagellum, leading to flagellar asymmetry, is clearly associated with the $\mathrm{NO}$-induced $\left[\mathrm{Ca}^{2+}\right]_{\mathrm{i}}$ transient and subsequent oscillations (Fig. $3 \mathrm{C}$ ). We observed no effect on acrosomal status. Intriguingly, we have found that the effect of this stimulus protocol is bi-modal. Exactly the same treatment can induce a transient reduction in $\left[\mathrm{Ca}^{2+}\right]_{i}$ upon application of NO. Both types of response can occur in cells from the same semen sample, but we do not observe extreme versions of both response patterns in the same experiment. The basis for the remarkable variability of response in cells exposed to this protocol is far from clear, but it may well be relevant that, though S-nitrosylation can potentiate opening of RyR (Stoyanovsky et al., 1997; Xu et al., 1998), inhibition of these $\mathrm{Ca}^{2+}$ channels can occur under strongly nitrosylating conditions or at high doses of NO (Zahradnikova et al., 1997; Hart and Dulhunty, 2000; Zima and Blatter, 2006). Mobilisation of stored $\mathrm{Ca}^{2+}$ by $\mathrm{NO}$ may thus have a bell-shaped dose response curve similar to that for the action of $\mathrm{IP}_{3}$ on $\mathrm{IP}_{3} \mathrm{Rs}$.

We propose that in their effects both on mobilisation of stored $\mathrm{Ca}^{2+}$ and on regulation of flagellar activity, progesterone and NO converge at a key site, resulting in complex interaction. Since progesterone and NO are both products of the cumulus oophorous (Machado-Oliveira et al., in prep), the strong synergistic effect seen in some cells (Fig. 3B) is potentially of considerable significance in vivo. The site of this agonist interaction is yet to be established, but as described above, the RyR must be a prime candidate. At least two mechanisms might contribute to the synergistic interaction of progesterone and $\mathrm{NO}$ (Fig. 4): i) Low dose progesterone may provide a tonic, 'background' influx of $\mathrm{Ca}^{2+}$ that allows the store to fill up, such that a an immediate, significant release of $\mathrm{Ca}^{2+}$ occurs upon exposure to NO. NO itself might enhance this effect since generation of cGMP may lead to the activation of $\mathrm{Ca}^{2+}$ permeable channels in

Fig. 4. Tentative model for synergistic interaction of $\mathrm{pM}$ concentrations of progesterone and nitric oxide in mobilising $\mathrm{Ca}^{2+}$ from the intracellular store in the neck region of human sperm. Gating of $\mathrm{Ca}^{2+}$ permeable channels by progesterone causes a modest increase in $\mathrm{Ca}^{2+}$ 'leak' into the sperm (1), leading to elevation of resting $\left[\mathrm{Ca}^{2+}\right]_{i}$ and accumulation of $\mathrm{Ca}^{2+}$ into the store $\left(\left[\mathrm{Ca}^{2+}\right]_{s}\right)(\mathbf{2})$. Application of nitric oxide $(\mathrm{NO} \bullet$ ) results in nitrosylation of ryanodine receptors (green rectangle) in the membrane of the sperm neck store (3). Depending on conditions in the cell prior to nitric oxide exposure, this may increase or reduce open probability of ryanodine receptors (see text). Where nitrosylation increases open probability of ryanodine receptors, $\mathrm{Ca}^{2+}$ mobilisation is enhanced by progesterone pre-treatment because the store has now been filled with $\mathrm{Ca}^{2+}(\mathbf{4})$ and/or because the effect of nitrosylation on ryanodine receptor open probability is enhanced due to elevated cytoplasmic $\left(\left[\mathrm{Ca}^{2+}\right]_{i}\right)(\mathbf{5})$. In the absence of progesterone pretreatment, stimulation of soluble guanylate cyclase (sGC) by nitric oxide, and consequent activation (directly or indirectly) of $\mathrm{Ca}^{2+}$ permeable channels in the plasmalemma (CNG; 7) may be necessary to support mobilisation of stored $\mathrm{Ca}^{2+}$. 
the sperm plasmalemma; ii) Exposure to pM concentrations of progesterone clearly increases resting $\left[\mathrm{Ca}^{2+}\right]_{i}$ in some cells and it is likely that in others the rise is too small or too localised to be detected. Such an increase may be insufficient to induce $\mathrm{Ca}^{2+}$-induced $\mathrm{Ca}^{2+}$ release prior to $\mathrm{NO}$ exposure, but might become so after the release mechanism is sensitised by $\mathrm{S}$ nitrosylation (Aracena et al., 2003).

\section{4-aminopyridine, $\mathrm{Ca}^{2+}$ mobilisation and hyperactivation}

When 4-aminopyridine $(2 \mathrm{mM})$ is applied to a population of human sperm the percentage of hyperactivated cells, as assessed by computer-assisted semen analysis (CASA) increases 'immediately'. The proportion of cells assessed as Sort 7 (hyperactivated) increases from 3-4\% to $40-50 \%$ (Fig. 5A) and shows little decay over a period of $40 \mathrm{~min}$ (Gu et al., 2004; S Costello unpublished data). This effect is similar in amplitude whether cells are prepared by incubation in capacitating medium (supplemented EBSS containing $25 \mathrm{mM}$ bicarbonate, $0.3 \% \mathrm{BSA}$ ) for 5-6 h or for just 1-1.5 h, a point at which changes associated with capacitation are not complete (Bedu-Addo et al., 2005). Thus 4-aminopyridine is one of the most potent inducers of human sperm hyperactivation yet described. The signalling mechanisms that govern hyperactivation are not yet clear, but an increase in intracellular $\mathrm{Ca}^{2+}$ in the principal piece and/or mid-piece of the flagellum is apparently key to initiation and maintenance of hyperactivation (Suarez and Dai, 1995; Carlsen et al., 2003; Quill et al., 2003; Marquez et al., 2007). We therefore investigated whether exposure of human sperm to 4-aminopyridine, at a concentration sufficient to induce hyperactivation, caused an elevation of $\left[\mathrm{Ca}^{2+}\right]_{i}$.

Application of $2 \mathrm{mM} 4$-aminopyridine caused a dose dependent, tonic increase in $\left[\mathrm{Ca}^{2+}\right]_{i}$ in human sperm. This was clearly visible in fluorimetric records from populations and in imaging experiments a similar sustained, reversible rise in $\left[\mathrm{Ca}^{2+}\right]_{i}$ occurred in the neck-midpiece region associated with asymmetric bending of the proximal flagellum (Fig. 5B). 4-aminopyridine is widely used as a $\mathrm{K}^{+}$channel blocker (Alexander et al., 2006), but this effect of the drug was apparently independent of any actions on $\mathrm{K}^{+}$fluxes (and consequently on voltage-regulated $\mathrm{Ca}^{2+}$-permeable channels) since similar responses occurred when Em was 'clamped' by pre-incubating cells with the $\mathrm{K}^{+}$-ionophore valinomycin. $\mathrm{A}$ possible alternative mechanism of action of 4-aminopyridine on $\left[\mathrm{Ca}^{2+}\right]_{\mathrm{i}}$ is by mobilisation of stored $\mathrm{Ca}^{2+}$, an effect that has been observed in a number of mammalian cell types (Ishida and Honda, 1993; Cabado et al., 2000; Grimaldi et al., 2001). Furthermore, the amplitude of the response to 4-aminopyridine was not altered when cells were super-fused with 4-aminopyridine in 'nominally $\mathrm{Ca}^{2+}$-free' medium. However, when cells in 'nominally $\mathrm{Ca}^{2+}$-free' medium were pre-treated with bis-phenol, an inhibitor of both sarcoplasmic endoplasmic reticulum $\mathrm{Ca}^{2+}$ ATPase and the secretory pathway $\mathrm{Ca}^{2+}$ ATPase intracellular $\mathrm{Ca}^{2+}$ pumps (Brown et al., 1994; Harper et al., 2005), the response to 4aminopyridine was greatly reduced. Exposure of human sperm to EGTA-buffered, 'Ca ${ }^{2+}$ free' medium rapidly depletes intracellular $\mathrm{Ca}^{2+}$ stores (Harper et al., 2004; Bedu-Addo et al., 2007). Cells incubated in EGTA-buffered saline for 10 -15 min showed no response to 4-aminopyridine, but application of the drug 4-5 $\mathrm{min}$ after exposure to EGTA induced a clear response in almost $25 \%$ of cells. Under these circumstances the rise in $\left[\mathrm{Ca}^{2+}\right]_{\mathrm{i}}$ was tran- sient and was of diminished amplitude. Thus it appears that at least part of the elevation in $\left[\mathrm{Ca}^{2+}\right]_{\mathrm{i}}$ that occurs in human sperm exposed to 4-aminopyridine reflects the mobilisation of stored $\mathrm{Ca}^{2+}$, though the prolonged effect is probably dependent upon $\mathrm{Ca}^{2+}$-influx (see below).

We used CASA to examine whether mobilisation of stored $\mathrm{Ca}^{2+}$ might contribute to the strong hyperactivating action of 4aminopyridine on human sperm. The ability of 4-aminopyridine dramatically to increase the proportion of hyperactivated cells was not inhibited by simple omission of $\mathrm{Ca}^{2+}$ from the medium, the ability of the drug to induce hyperactivation being, if anything, enhanced. Furthermore, following brief re-suspension in EGTA buffered saline, application of $2 \mathrm{mM} 4$-aminopyridine induced hyperactivation in a proportion of cells only slightly lower than that in controls (standard medium; Fig. 5A). However, after incubation in EGTA-buffered medium for 20 min the proportion of motile cells was decreased (by one third) and the hyperactivating effect of 4aminopyridine was significantly reduced (though not abolished; Fig. 5A). It appears that mobilisation of $\mathrm{Ca}^{2+}$ from a labile, EGTAsensitive store, contributes to the ability of 4-aminopyridine to induce hyperactivation. These findings are consistent with previous reports that extra-cellular calcium is not a requirement for initiation of hyperactivation in bovine and murine sperm. Suarez and colleagues concluded that mobilisation of stored $\mathrm{Ca}^{2+}$ (possibly from the redundant nuclear envelope) is able to initiate but cannot sustain hyper-activated motility (Ho and Suarez 2001; Marquez et al., 2007). Significantly, treatment of human sperm with 4-aminopyridine did not increase the occurrence of acrosome reaction in cells incubated under capacitating conditions.

Though 4-aminopyridine may initiate hyperactivation by mobilising stored $\mathrm{Ca}^{2+}$, the ability to cause prolonged elevation of $\left[\mathrm{Ca}^{2+}\right]_{\mathrm{i}}$ (and maintained hyperactivation) must require activation of $\mathrm{Ca}^{2+}$ permeable channels in the plasma membrane. In many cells store depletion triggers $\mathrm{Ca}^{2+}$ influx via capacitative $\mathrm{Ca}^{2+}$ influx (store operated calcium channels), which act to maintain a prolonged $\mathrm{Ca}^{2+}$ signal and to refill the mobilised store (Fig. 1B). Thus, depletion of stored calcium in sperm, probably from stores in the neck region of the cell (Ho and Suarez, 2001; NaabyHansen et al., 2001; Harper etal., 2004) could activate local storeoperated $\mathrm{Ca}^{2+}$-channels in the flagellum to promote and prolong hyperactivation. 4-aminopyridine may potentiate activity of such channels (Grimaldi et al., 2001). However, it has been demonstrated recently that 4-aminopyridine greatly enhances activity of the $\mathrm{pH}$-sensitive sperm $\mathrm{K}^{+}$current $\mathrm{I}_{\mathrm{KSper}}$ in mouse sperm principal piece by cytoplasmic alkalinisation (Navarro et al., 2007). Since the sperm-specific, $\mathrm{pH}$-sensitive $\mathrm{Ca}^{2+}$-permeable CatSper is similarly localised (Ren et al., 2001; Kirichok et al., 2006) and is also pH sensitive (Kirichok et al., 2006), an alternative explanation is that 4-aminopyridine induces $\mathrm{Ca}^{2+}$-influx in the sperm tail (and sustained hyperactivation) by activation of $\mathrm{I}_{\text {CatSper }}$. To investigate this possibility, we super-fused sperm with saline adjusted to $\mathrm{pH}$ 8.5. In simple medium human sperm are ' $\mathrm{pH}$-compliant', $\mathrm{pH}_{\mathrm{i}}$ being approximately 0.4 units less than the external $\mathrm{pH}$ over a range from 7.2 to 8.2 (Hamamah et al., 1996). Elevation of $\mathrm{pH}_{\mathrm{o}}$ from 7.5 to 8.5 might thus be expected to raise $\mathrm{pH}_{\mathrm{i}}$ by as much as one unit. As expected, upon super-fusion with medium at $\mathrm{pH} 8.5$ (replacing standard medium at $\mathrm{pH} 7.4$ ) we observed a sustained increase in $\left[\mathrm{Ca}^{2+}\right]_{\mathrm{i}}$, probably reflecting activation of CatSper channels. Surprisingly, this pre-treatment did not occlude the response to 
Fig. 5. Hyperactivation and $\mathrm{Ca}^{2+}$ signals in 4-aminopyridine-treated in human sperm. (A) Stimulation of hyperactivation by $2 \mathrm{mM}$ 4-aminopyridine. The percentage of hyperactivated cells (sort 7) approximately 1 2 min after application of 4-aminopyridine is increased more than 10-fold compared to that in untreated cells (white bars). Omission of $\mathrm{Ca}^{2+}$ from the medium does not inhibit this effect (yellow bar). When cells are suspended in EGTA-buffered medium prior to treatment (blue bars) the ability of 4-aminopyridine to stimulate hyperactivation is gradually lost, the response being $<50 \%$ of that in controls after 15-20 min. (B) Upper panel shows 'typical' effect of 4-aminopyridine on $\left[\mathrm{Ca}^{2+}\right]_{i}$ (change in fluorescence of Oregon Green BAPTA 1) in human sperm. Upon superfusion with $2 \mathrm{mM} 4$-aminopyridine (pink shading) fluorescence rises by 20-30\% within 1-2 min and stabilises. Upon washout of 4-

A

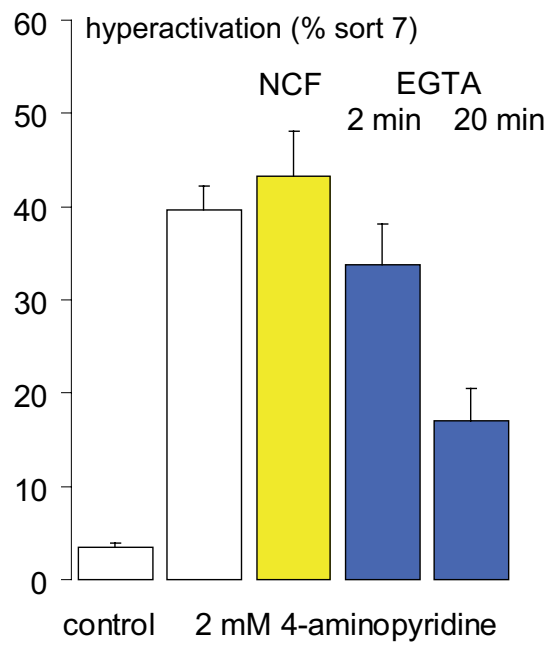

B

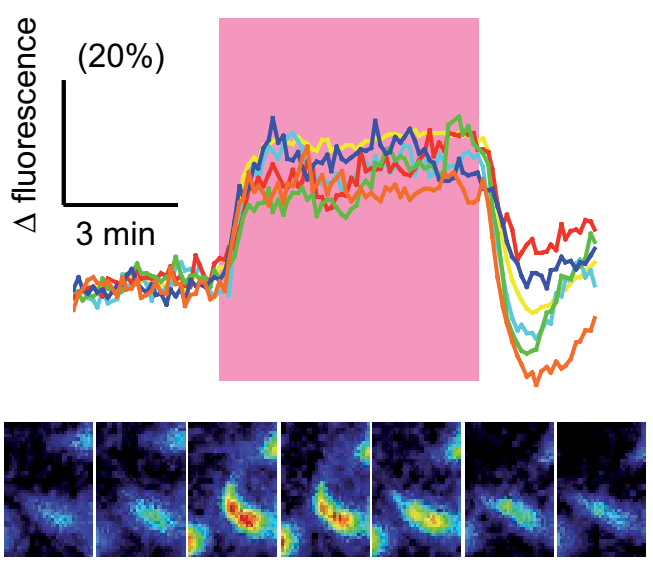

aminopyridine $\left[\mathrm{Ca}^{2+}\right]_{i}$ immediately falls to levels at or near those observed before treatment, sometimes with an 'undershoot' of 2-3 min duration. Responses of 6 separate cells are shown. Lower panel shows a series of pseudo-coloured images (warm colours show high [Ca $\left.{ }^{2+}\right]_{i}$ ) of a cell treated with $2 \mathrm{mM}$ 4-aminopyridine. First two images are prior to treatment, images 3 and 4 are during 4-aminopyrine super-fusion and images 5-7 are during and after washout. Note that there is a marked flexure (a clear change in angle between the midline of the head and proximal flagellum) during 4aminopyridine exposure that 'relaxes' immediately upon washout of the drug.

subsequent application of 4-aminopyridine. These results suggest that the 4-aminopyridine induced $\mathrm{Ca}^{2+}$-influx may not be solely $\mathrm{pH} / \mathrm{CatSper}$ dependent and that modulation of capacitative $\mathrm{Ca}^{2+}$ influx may play a role in this effect. We tentatively conclude that hyperactivation of human sperm that occurs upon exposure to 4-aminopyridine may, in a number of ways, parallel the induction of hyperactivation in bovine sperm induced by manoeuvres designed to mobilise stored $\mathrm{Ca}^{2+}$ (Ho and Suarez, 2001; 2003)

\section{The $\mathrm{Ca}^{2+}$ signal repertoire of sperm - an unusually hard-wired cell?}

In this review we have concentrated on our current focus of interest, the mobilisation of stored $\mathrm{Ca}^{2+}$ in the neck region of the sperm and its putative contribution to the regulation of motility and hyperactivation. But this is only a small part of a much more complex pattern of $\left[\mathrm{Ca}^{2+}\right]_{i}$ signalling in sperm (Publicover et al., 2007). Studies of the zona pellucida-induced acrosome reaction show a central and complex role for $\mathrm{Ca}^{2+}$ signalling, but also clearly show that the pathway and $\mathrm{Ca}^{2+}$-signalling components involved are different to those described above (Florman et al., 1998; O'Toole et al., 2000; Tomes, 2007). More recently, work on responses of sperm to chemotactic cues has shed new light on the $\mathrm{Ca}^{2+}$-mediated signalling events that underlie chemotaxis (Eisenbach and Giojalas, 2006; Kaupp et al., 2006; Spehr etal., 2006). Perhaps not surprisingly, hyperactivation, acrosome reaction and chemotactic responses each involve a $\left[\mathrm{Ca}^{2+}\right]_{i}$ signal with discrete spatio-temporal characteristics. Should we be surprised that sperm can do this?

The mature sperm cell is clearly 'simplified', lacking much of the intracellular structure and organisation that is present in undifferentiated germ cells. However, not only do sperm retain the molecular components of the somatic cell $\mathrm{Ca}^{2+}$ signalling toolkit, but they even introduce new ones of their own (CatSpers; see contribution by D Clapham). Furthermore, the extreme level of structural and functional polarisation that is seen in a mature sperm 'pre-adapts' the cell for flexible use of a diffusible messenger, despite its small size. It appears that (at least for rapidly acting stimulus-response pathways) sperm use a small number of parallel but separate $\mathrm{Ca}^{2+}$ signalling pathways. On the basis of the available data we would suggest that agonists of acrosome reaction, hyperactivation and chemotaxis each mobilise a different source of $\mathrm{Ca}^{2+}$, in different places and with different $\left[\mathrm{Ca}^{2+}\right]_{i}$ kinetics. In the case of stored $\mathrm{Ca}^{2+}$ the mechanism of store mobilisation may even differ between the acrosomal and neck stores. Progesterone and NO apparently converge in their effects on the $\mathrm{Ca}^{2+}$ store at the sperm neck, but whether each of the $\mathrm{Ca}^{2+}$ signalling pathways of sperm integrate multiple inputs is not yet clear. Chemotaxis is particularly interesting in this respect. Chemotaxis in human sperm can apparently be induced by several agonists (Eisenbach and Giojalas, 2006) and therefore via several receptors, yet convergence of input from more than one chemical gradient would potentially 'confuse' the orientation of the cell. One possible answer is that transduction pathways of chemo-attractants do converge, but activation of the receptors occurs sequentially, as the sperm ascends the female tract, rather than simultaneously (Eisenbach and Giojalas, 2006). Thus $\mathrm{Ca}^{2+}$-signalling in sperm, though similar in most ways to that in somatic cells, may be more 'hard-wired' than in most cells, having direct and 'simple' connections between inputs and outputs of $\mathrm{Ca}^{2+}$ signalling pathways in order to minimise potentially dangerous cross-talk in a very small cell (Fig. 1A (iii)). Inevitably some spatial overlap of signals occurs, but each signal has its own temporal and spatial characteristics which may be sufficiently selective to activate a specific target (Johnson and Chang, 2000). In human sperm populations, where many cells are (according to standard semen analysis) not normal, inappropri- 
ate 'leakage' between $\mathrm{Ca}^{2+}$ signal pathways may not be an uncommon event and, in extreme cases, will cause idiopathic male subfertility. Premature induction of acrosome reaction by high doses of progesterone, which would render the cell unable to fertilise (Harper and Publicover, 2005) is an example of such signal 'leakage'.

\section{Acknowledgements}

This work was supported by the Wellcome Trust, Fundação para a Ciência e Tecnologia (G. M. -O.) and The Ghanian High Commission (K. B. - .).

\section{References}

AITKEN R. J., BUCKINGHAM D. W. and IRVINE D. S. (1996) The extragenomic action of progesterone on human spermatozoa: Evidence for a ubiquitous response that is rapidly down-regulated. Endocrinology 137: 3999-4009.

AITKEN R. J. and MCLAUGHLIN E. A. (2007) Molecular mechanisms of sperm capacitation: Progesterone-induced secondary calcium oscillations reflect the attainment of a capacitated state. Soc Reprod Fertil Supp/63: 273-93.

ALEXANDER S. P., MATHIE A. and PETERS J. A. (2006) Guide to receptors and channels, 2nd edition. Br J Pharmaco/147 Suppl 3: S1-168.

ARACENA P., SANCHEZ G., DONOSO P., HAMILTON S. L. and HIDALGO C. (2003) S-glutathionylation decreases Mg2+ inhibition and s-nitrosylation enhances Ca2+ activation of ryr1 channels. J Biol Chem 278: 42927-35.

BALDI E., CASANO R., FALSETTI C., KRAUSZ C., MAGGI M. and FORTI G. (1991) Intracellular calcium accumulation and responsiveness to progesterone in capacitating human spermatozoa. J Andro/12: 323-30.

BEDU-ADDO K., BARRATT C. L., KIRKMAN-BROWN J. C. and PUBLICOVER S. J. (2007) Patterns of [ca2+](i) mobilization and cell response in human spermatozoa exposed to progesterone. Dev Bio/302: 324-32.

BEDU-ADDO K., LEFIEVRE L., MOSELEYF. L., BARRATT C. L. and PUBLICOVER S. J. (2005) Bicarbonate and bovine serum albumin reversibly 'switch' capacitation-induced events in human spermatozoa. Mol Hum Reprod 11: 683-91.

BERRIDGE M. J. (1997) The am and fm of calcium signalling. Nature 386: 759-60.

BERRIDGE M. J. (2004) Calcium signal transduction and cellular control mechanisms. Biochim Biophys Acta 1742: 3-7.

BERRIDGE M. J. (2006) Remodelling Ca2+ signalling systems and cardiac hypertrophy. Biochem Soc Trans 34: 228-31.

BLACKMORE P. F. (1993) Thapsigargin elevates and potentiates the ability of progesterone to increase intracellular free calcium in human sperm: Possible role of perinuclear calcium. Cell Calcium 14: 53-60.

BLACKMORE P. F., BEEBE S. J., DANFORTH D. R. and ALEXANDER N. (1990) Progesterone and 17 alpha-hydroxyprogesterone. Novel stimulators of calcium influx in human sperm. $J$ Biol Chem 265: 1376-80.

BLACKMORE P. F. and EISOLDT S. (1999) The neoglycoprotein mannose-bovine serum albumin, but not progesterone, activates t-type calcium channels in human spermatozoa. Mol Hum Reprod5: 498-506.

DARSZON A., NISHIGAKI T., WOOD C., TREVINO C. L., FELIX R. and BELTRAN C. (2005) Calcium channels and Ca2+ fluctuations in sperm physiology. Int Rev Cyto/243: 79-172.

DORVAL V., DUFOUR M. and LECLERC P. (2003) Role of protein'tyrosine phosphorylation in the thapsigargin-induced intracellular $\mathrm{Ca} 2+$ store depletion during human sperm acrosome reaction. Mol Hum Reprod 9: 125-31.

DRAGILEVA E., RUBINSTEIN S. and BREITBART H. (1999) Intracellular Ca2+$\mathrm{Mg} 2+-$ atpase regulates calcium influx and acrosomal exocytosis in bull and ram spermatozoa. Biol Reprod 61: 1226-34.

EISENBACH M. and GIOJALAS L. C. (2006) Sperm guidance in mammals - an unpaved road to the egg. Nat Rev Mol Cell Bio/7: 276-85.

EVANS R. M. and ZAMPONI G. W. (2006) Presynaptic Ca2+ channels-integration centers for neuronal signaling pathways. Trends Neurosci29: 617-24.

FELIX R. (2005) Molecular physiology and pathology of Ca2+-conducting channels in the plasma membrane of mammalian sperm. Reproduction 129: 251-62.
FLIEGERT R., GASSER A. and GUSE A. H. (2007) Regulation of calcium signalling by adenine-based second messengers. Biochem Soc Trans 35: 109-14.

FORESTA C., ROSSATO M. and DI VIRGILIO F. (1993) Ion fluxes through the progesterone-activated channel of the sperm plasma membrane. Biochem $\mathrm{J}$ 294: 279-83.

FRASER L. R. (1995) Mechanisms regulating capacitation and the acrosome reaction. In: FENICHEL P. and PARINAUD J. (eds.) Human sperm acrosome reaction, pp. 17-33: Colloque/INSERIM John Libbey Eurotext Ltd, Montrogue, France.

FURUNO T. (2005) Confocal laser scanning microscopy to study molecular mechanism of mast cell activation. Yakugaki Zasshi 125: 671-83

GALINDO B. E., BELTRAN C., CRAGOE E. J., JR. and DARSZON A. (2000) Participation of a $\mathrm{K}+$ channel modulated directly by cgmp in the speract-induced signaling cascade of strongylocentrotus purpuratus sea urchin sperm. Dev Biol 221: 285-94.

GAUSS R., SEIFERT R. and KAUPP U. B. (1998) Molecular identification of a hyperpolarization-activated channel in sea urchin sperm. Nature 393: 583-7.

GRIMALDI M., ATZORI M., RAY P. and ALKON D. L. (2001) Mobilization of calcium from intracellular stores, potentiation of neurotransmitter-induced calcium transients, and capacitative calcium entry by 4-aminopyridine. JNeurosci21: 313543.

GUY., KIRKMAN-BROWN J. C., KORCHEVY., BARRATT C. L. and PUBLICOVER S. J. (2004) Multi-state, 4-aminopyridine-sensitive ion channels in human spermatozoa. Dev Bio/274: 308-17.

GUERINI D., COLETTO L. and CARAFOLI E. (2005) Exporting calcium from cells. Cell Calcium 38: 281-9.

GUERINI M. N., BEHNKE M. S. and WHITE M. W. (2005) Biochemical and genetic analysis of the distinct proliferating cell nuclear antigens of toxoplasma gondii. Mol Biochem Parasitol 142: 56-65.

GUNARATNE H. J., NEILL A. T. and VACQUIER V. D. (2006) Plasma membrane calcium atpase is concentrated in the head of sea urchin spermatozoa. J Cell Physio/207: 413-9.

GUNARATNE H. J. and VACQUIER V. D. (2006) Evidence for a secretory pathway ca2+-atpase in sea urchin spermatozoa. FEBS Lett 580: 3900-4.

GWATHMEY T., BLACKMORE P. F. and MAHONY M. C. (2000) Progesteroneinduced calcium influx in cynomolgus monkey (macaca fascicularis) spermatozoa. J Andro/21: 534-40.

HAMAMAH S., MAGNOUX E., ROYERE D., BARTHELEMY C., DACHEUX J. L. and GATTI J. L. (1996) Internal ph of human spermatozoa: Effect of ions, human follicular fluid and progesterone. Mol Hum Reprod 2: 219-24.

HARPER C. V., KIRKMAN-BROWN J. C., BARRATT C. L. and PUBLICOVER S. J. (2003) Encoding of progesterone stimulus intensity by intracellular [ca2+] ([ca2+]i) in human spermatozoa. Biochem J372: 407-17.

HARPER C. V., BARRATT C. L. and PUBLICOVER S. J. (2004) Stimulation of human spermatozoa with progesterone gradients to simulate approach to the oocyte. Induction of [Ca2+]i oscillations and cyclical transitions in flagellar beating. J Biol Chem 279: 46315-25.

HARPER C., WOOTTON L., MICHELANGELI F., LEFIEVRE L., BARRATT C. and PUBLICOVER S. (2005) Secretory pathway Ca2+-ATPase (spca1) ca(2)+ pumps, not sercas, regulate complex [Ca2+](i) signals in human spermatozoa. $J$ Cell SCi118: 1673-85.

HARPER C.V., BARRATT C.L., PUBLICOVER S.J., and KIRKMAN-BROWN J.C (2006) Kinetics of the progesterone-induced acrosome reaction and its relation to intracellular calcium responses in individual human spermatozoa. Biol Reprod 75:933-9.

HARPER C. V. and PUBLICOVER S. J. (2005) Reassessing the role of progesterone in fertilization-compartmentalized calcium signalling in human spermatozoa? Hum Reprod 20: 2675-80.

HART J. D. and DULHUNTY A. F. (2000) Nitric oxide activates or inhibits skeletal muscle ryanodine receptors depending on its concentration, membrane potential and ligand binding. J Membr Bio/173: 227-36.

HERRERO M.B., CEBRAL E., BOQUET M., VIGGIANO J.M., VITULLO A. and GIMENO M.A. (1994) Effect of nitric oxide on mouse sperm hyperactivation. Acta Physiol Pharmacol Ther Latinoam 44:65-9.

HERRERO M.B., VIGGIANO J.M., PÉREZ MARTíNEZ S. and DE GIMENO M.F. 
(1997) Evidence that nitric oxide synthase is involved in progesterone-induced acrosomal exocytosis in mouse spermatozoa. Reprod Fertil Dev 9:433-9.

HERRICK S. B., SCHWEISSINGER D. L., KIM S. W., BAYAN K. R., MANN S. and CARDULLO R. A. (2005) The acrosomal vesicle of mouse sperm is a calcium store. J Cell Physio/202: 663-71.

HEUNKS L. M., MACHIELS H. A., DEKHUIJZEN P. N., PRAKASHY. S. and SIECK G. C. (2001) Nitric oxide affects sarcoplasmic calcium release in skeletal myotubes. J App/ Physio/91: 2117-24.

HO H. C., GRANISH K. A. and SUAREZ S. S. (2002) Hyperactivated motility of bull sperm is triggered at the axoneme by $\mathrm{Ca} 2+$ and not camp. Dev Bio/250: 20817.

HO H. C. and SUAREZ S. S. (2001) An inositol 1,4,5-trisphosphate receptor-gated intracellular $\mathrm{Ca} 2+$ store is involved in regulating sperm hyperactivated motility. Biol Reprod 65: 1606-15.

JAGANNATHAN S., PUNT E. L., GU Y., ARNOULT C., SAKKAS D., BARRATT C. L. and PUBLICOVER S. J. (2002) Identification and localization of t-type voltage-operated calcium channel subunits in human male germ cells. Expression of multiple isoforms. J Biol Chem 277: 8449-56.

JAISWAL B. S., TUR-KASPA I., DOR J., MASHIACH S. and EISENBACH M. (1999) Human sperm chemotaxis: Is progesterone a chemoattractant? Bio/Reprod60: 1314-9.

JIMENEZ-GONZALEZ C., MICHELANGELI F., HARPER C. V., BARRATT C. L. and PUBLICOVER S. J. (2006) Calcium signalling in human spermatozoa: A specialized 'toolkit' of channels, transporters and stores. Hum Reprod Update 12: $253-67$.

JOHNSON J. D. and CHANG J. P. (2000) Function- and agonist-specific ca2+ signalling: The requirement for and mechanism of spatial and temporal complexity in Ca2+ signals. Biochem Cell Biol78: 217-40.

KIRICHOK Y., NAVARRO B. and CLAPHAM D. E. (2006) Whole-cell patch-clamp measurements of spermatozoa reveal an alkaline-activated ca2+ channel. Nature 439: 737-40.

KIRKMAN-BROWN J. C., BARRATT C. L. and PUBLICOVER S. J. (2004) Slow calcium oscillations in human spermatozoa. Biochem J378: 827-32.

KIRKMAN-BROWN J. C., PUNT E. L., BARRATT C. L. and PUBLICOVER S. J. (2002) Zona pellucida and progesterone-induced Ca2+ signaling and acrosome reaction in human spermatozoa. J Andro/23: 306-15.

KOBORI H., MIYAZAKI S. and KUWABARA Y. (2000) Characterization of intracellular $\mathrm{Ca} 2+$ increase in response to progesterone and cyclic nucleotides in mouse spermatozoa. Biol Reprod63: 113-20.

KRETSINGER R. H. (1979) The informational role of calcium in the cytosol. $A d v$ Cyclic Nucleotide Res 11: 1-26.

LAWSON C., DORVAL V., GOUPIL S. and LECLERC P. (2007) Identification and localisation of serca 2 isoforms in mammalian sperm. Mol Hum Reprod13: 307 16.

LI N., ZOU A. P., GE Z. D., CAMPBELL W. B. and LI P. L. (2000) Effect of nitric oxide on calcium-induced calcium release in coronary arterial smooth muscle. Gen Pharmaco/35: 37-45.

LIU D. Y., GARRETT C. and BAKER H. W. (2006) Acrosome-reacted human sperm in insemination medium do not bind to the zona pellucida of human oocytes. Int $J$ Andro/29: 475-81.

MARQUEZ B., IGNOTZ G. and SUAREZS. S. (2007) Contributions of extracellular and intracellular ca2+ to regulation of sperm motility: Release of intracellular stores can hyperactivate catsper1 and catsper2 null sperm. Dev Bio/303: 21421.

MEIZEL S. (2004) The sperm, a neuron with a tail: 'neuronal' receptors in mammalian sperm. Biol Rev Camb Philos Soc 79: 713-32.

MEIZEL S. and TURNER K. O. (1993) Initiation of the human sperm acrosome reaction by thapsigargin. $J$ Exp Zoo/267: 350-5.

MEIZEL S., TURNER K. O. and NUCCITELLI R. (1997) Progesterone triggers a wave of increased free calcium during the human sperm acrosome reaction. Dev Biol182: 67-75.

NAABY-HANSEN S., WOLKOWICZ M. J., KLOTZ K., BUSH L. A., WESTBROOK V. A., SHIBAHARA H., SHETTY J., COONROD S. A., REDDI P. P., SHANNON J., KINTER M., SHERMAN N. E., FOX J., FLICKINGER C. J. and HERR J. C. (2001) Co-localization of the inositol 1,4,5-trisphosphate receptor and calreticulin in the equatorial segment and in membrane bounded vesicles in the cytoplasmic droplet of human spermatozoa. Mol Hum Reprod 7: 923-33.

NAVARRO B., KIRICHOK Y. and CLAPHAM D. E. (2007) Ksper, a ph-sensitive k+ current that controls sperm membrane potential. Proc Natl Acad Sci USA 104 7688-92.

OKUNADE G.W., MILLER M.L., PYNE G.J., SUTLIFF R.L., O'CONNOR K.T., NEUMANN J.C., ANDRINGA A., MILLER D.A., PRASAD V., DOETSCHMAN T. PAUL R.J and SHULL G.E. (2004) Targeted ablation of plasma membrane Ca2+-ATPase (PMCA) 1 and 4 indicates a major housekeeping function for PMCA1 and a critical role in hyperactivated sperm motility and male fertility for PMCA4. J Biol Chem 279:33742-33750.

O'TOOLE C. M., ARNOULT C., DARSZON A., STEINHARDT R. A. and FLORMAN H. M. (2000) Ca2+ entry through store-operated channels in mouse sperm is initiated by egg zp3 and drives the acrosome reaction. Mol Biol Cel/11: 157184.

PETERSEN O. H., SUTTON R. and CRIDDLE D. N. (2006) Failure of calcium microdomain generation and pathological consequences. Cel/ Calcium40: 593600.

PLANT A., MCLAUGHLIN E. A. and FORD W. C. (1995) Intracellular calcium measurements in individual human sperm demonstrate that the majority can respond to progesterone. Fertil Steril64: 1213-5

PUBLICOVER S., HARPER C. V. and BARRATT C. (2007) [ca2+]i signalling in sperm-making the most of what you've got. Nat Cell Bio/9: 235-42.

REVELLI A., COSTAMAGNA C., MOFFA F., ALDIERI E., OCHETTI S., BOSIA A., MASSOBRIO M., LINDBLOM B. and GHIGO D. (2001) Signaling pathway of nitric oxide-induced acrosome reaction in human spermatozoa. Biol Reprod 64:1708-12

ROSSATO M., DI VIRGILIO F., RIZZUTO R., GALEAZZI C. and FORESTA C. (2001) Intracellular calcium store depletion and acrosome reaction in human spermatozoa: Role of calcium and plasma membrane potential. Mol Hum Reprod 7: 119-28.

RUFO G. A., JR., SCHOFF P. K. and LARDY H. A. (1984) Regulation of calcium content in bovine spermatozoa. J Biol Chem 259: 2547-52.

STOYANOVSKY D., MURPHY T., ANNO P. R., KIM Y. M. and SALAMA G. (1997) Nitric oxide activates skeletal and cardiac ryanodine receptors. Cel/ Calcium21: 19-29.

SCHUH K., CARTWRIGHT E.J., JANKEVICS E., BUNDSCHU K., LIEBERMANN J., WILLIAMS J.C., ARMESILLA A.L., EMERSON M., OCEANDY D., KNOBELOCH K.P. and NEYSES L. (2004) Plasma membrane Ca2+ATPase 4 is required for sperm motility and male fertility. J Bio/ Chem 279: 28220-28226.

TESARIK J., CARRERAS A. and MENDOZA C. (1996) Single cell analysis of tyrosine kinase dependent and independent $\mathrm{Ca} 2+$ fluxes in progesterone induced acrosome reaction. Mol Hum Reprod 2: 225-32.

THASTRUP O., CULLEN P. J., DROBAK B. K., HANLEY M. R. and DAWSON A. P. (1990) Thapsigargin, a tumor promoter, discharges intracellular ca2+ stores by specific inhibition of the endoplasmic reticulum ca2(+)-atpase. Proc Nat/ Acad Sci USA 87: 2466-70.

UHLER M. L., LEUNG A., CHAN S. Y. and WANG C. (1992) Direct effects of progesterone and antiprogesterone on human sperm hyperactivated motility and acrosome reaction. Fertil Steril58: 1191-8.

VISCONTI P. E., WESTBROOK V. A., CHERTIHIN O., DEMARCO I., SLEIGHT S and DIEKMAN A. B. (2002) Novel signaling pathways involved in sperm acquisition of fertilizing capacity. J Reprod Immuno/53: 133-50.

WENNEMUTH G., BABCOCK D. F. and HILLE B. (2003) Calcium clearance mechanisms of mouse sperm. J Gen Physio/122: 115-28.

WEYAND I., GODDE M., FRINGS S., WEINER J., MULLER F., ALTENHOFEN W., HATT H. and KAUPP U. B. (1994) Cloning and functional expression of a cyclicnucleotide-gated channel from mammalian sperm. Nature 368: 859-63.

WILLIAMS K. M. and FORD W. C. (2003) Effects of ca-atpase inhibitors on the intracellular calcium activity and motility of human spermatozoa. Int JAndro/26: 366-75.

WUYTACK F., RAEYMAEKERS L. and MISSIAEN L. (2003) Pmr1/spca ca2+ pumps and the role of the golgi apparatus as a ca2+ store. Pflugers Arch 446: 148-53.

XU L., EU J. P., MEISSNER G. and STAMLER J. S. (1998) Activation of the cardiac calcium release channel (ryanodine receptor) by poly-s-nitrosylation. Science 279: 234-7. 
YANAGIMACHI R. (1994) Fertility of mammalian spermatozoa: Its development and relativity. Zygote 2: 371-2.

YANAGIMACHI R. (1994b) The physiology of reproduction. New York: Raven Press.

YEOMAN R.R., JONES W.D. and RIZK B.M. (1998) Evidence for nitric oxide regulation of hamster sperm hyperactivation. J Androl. 19:58-64.

YANG J., SERRES C., PHILIBERT D., ROBEL P., BAULIEU E. E. and JOUANNET P. (1994) Progesterone and ru486: Opposing effects on human sperm. Proc Natl Acad Sci USA 91: 529-33.

ZAHRADNIKOVA A., MINAROVIC I., VENEMA R. C. and MESZAROS L. G. (1997) Inactivation of the cardiac ryanodine receptor calcium release channel by nitric oxide. Cel/ Calcium 22: 447-54.

ZAMIR N., BARKAN D., KEYNAN N., NAOR Z and BREITBART H. (1995) Atrial natriuretic peptide induces acrosomal exocytosis in bovine spermatozoa. $\mathrm{Am}$ J Physiol. 269:E216-21.

ZHANG H. G., DUAN X. G. and LIU R. Z. (2006) [ca2+ and sperm function]. Zhonghua Nan Ke Xue 12: 933-5.

ZHANG H. and ZHENG R. L. (1996). Possible role of nitric oxide on fertile and asthenozoospermic infertile human sperm functions. Free Radic Res 25, 347354.

ZIMA A. V. and BLATTER L. A. (2006) Redox regulation of cardiac calcium channels and transporters. Cardiovasc Res 71: 310-21.

\section{Related, previously published Int. J. Dev. Biol. articles}

See our recent Special Issue Developmental Biology in Poland edited by Tarkowski, Maleszewski and Kloc at: http://www.ijdb.ehu.es/web/contents. php?vol=52\&issue=2-3

See our recent Special Issue Ear Development edited by Fernando Giraldez and Bernd Fritzsch at: http://www.ijdb.ehu.es/web/contents.php?vol=51\&issue =6-7

Regionalized calcium signaling in zebrafish fertilization

Dipika Sharma and William H. Kinsey

Int. J. Dev. Biol. (2008) 52: 561-570

Defective calcium release during in vitro fertilization of maturing oocytes of LT/Sv mice Karolina Archacka, Anna Ajduk, Pawel Pomorski, Katarzyna Szczepanska, Marek Maleszewski and Maria A. Ciemerych Int. J. Dev. Biol. (2008) 52: doi: 10.1387/ijdb.072397ka

$\mathrm{Ca}^{2+}$-independent protein kinase $\mathrm{C}$ signalling in mouse eggs during the early phases of fertilization.

Carla Tatone, Simona Delle Monache, Antonella Francione, Luisa Gioia, Barbara Barboni and Rosella Colonna

Int. J. Dev. Biol. (2003) 47: 327-333

Parthenogenetic activation of mouse oocytes using calcium ionophores and protein kinase $\mathbf{C}$ stimulators.

J A Uranga, R A Pedersen and J Arechaga

Int. J. Dev. Biol. (1996) 40: 515-519

Mechanisms of initiation and propagation of the calcium wave during fertilization in deuterostomes.

F Berger

Int. J. Dev. Biol. (1993) 37: 245-262

Calcium in sea urchin egg during fertilization.

I Gillot, P Payan, J P Girard and C Sardet

Int. J. Dev. Biol. (1990) 34: 117-125

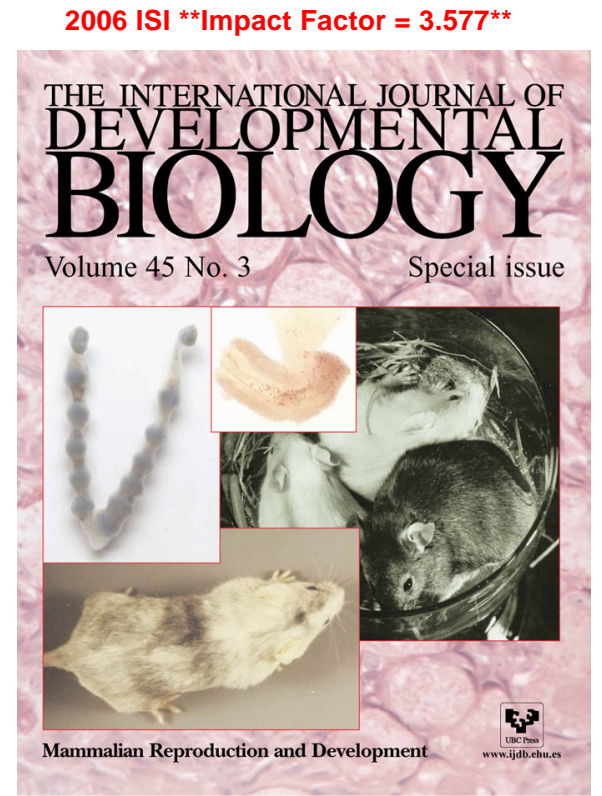

